\title{
Reseña del libro: Nuestro segundo cerebro \\ Las neuronas que dirigen el funcionamiento del intestino
}

\author{
Autor: Francisca Joly Gomez \\ Paidós | Año 2016 | ISBN: 97860077471479
}

DOI 10.46588/invurnus.v16i1.46

Recibido 22/04/2021

Aceptado 06/05/2021

Publicado 07/05/2021

El libro publicado por la editorial Booket Paidós, Nuestro segundo cerebro, Las neuronas que dirigen el funcionamiento del intestino, es una publicación qué hace incursionarnos hacia la reflexión y compresión de la salud como un engrane entre lo físico y lo emocional. En la actualidad el estilo de vida moderno es sedentario y acomodado, la dieta es abundante con alimentos procesados, comida rápida bajas en fibra dietética y otros nutrientes, esto se observa en un gran porcentaje de la población activa, y que ha dado como resultado el incremento de molestias intestinales como lo son las indigestiones, colitis y estreñimiento.

La autora de este libro, Francisca Joly Gomez, gastroenteróloga y nutrióloga de formación profesional, con especialidad en enfermedades intestinales raras de las qué casi no se mencionan, y por lo mismo su tratamiento es complejo, pretende con esta obra explicar de manera clara, sencilla y pedagógica el funcionamiento del intestino y el papel qué este juega en las enfermedades intestinales, y otras patologías como las alergias, afecciones neurológicas, qué aparentemente no tienen ninguna relación con este órgano qué forma parte del aparato digestivo, la autora menciona que hace más de diez años el intestino delgado ha sido objeto de varios estudios, sobre todo en pacientes enfermos de Parkinson, se le considera como un órgano complejo conformado por centres de millones de neuronas conectadas entre sí, qué emiten señales qué le permiten contraerse para participar en la digestión. 
De acuerdo con lo anterior, la tesis de la Dra. Francisca Joly Gomez pone de manifiesto en su obra qué el intestino delgado es el segundo "cerebro", es decir, este puede funcionar de manera independiente, y al mismo tiempo con una conexión coordinada con el cerebro, por lo qué su estudio y conocimiento es ineludible para las aplicaciones clínicas terapéuticas de las enfermedades, qué pueden estar relacionadas con el intestino delgado. La opinión de la autora sobre este tema me hace pensar qué es esencial estudiar interiormente al intestino delgado para comprender y entender su funcionamiento, específicamente el reto qué representa el papel fundamental del intestino delgado en la digestión, nutrición y en la salud.

De esta manera, la Dra. Francisca Joly Gomez nos ofrece con su obra además del tema central una gran oportunidad de adentrarse a conceptos e información práctica para introducir en nuestra vida cotidiana elementos importantes como lo son los probióticos, alimentos funcionales y otras prácticas para mantener la salud de nuestro segundo cerebro, el intestino.

Dra. Addy Leticia Zarza García

Universidad Autónoma del Carmen, Campeche

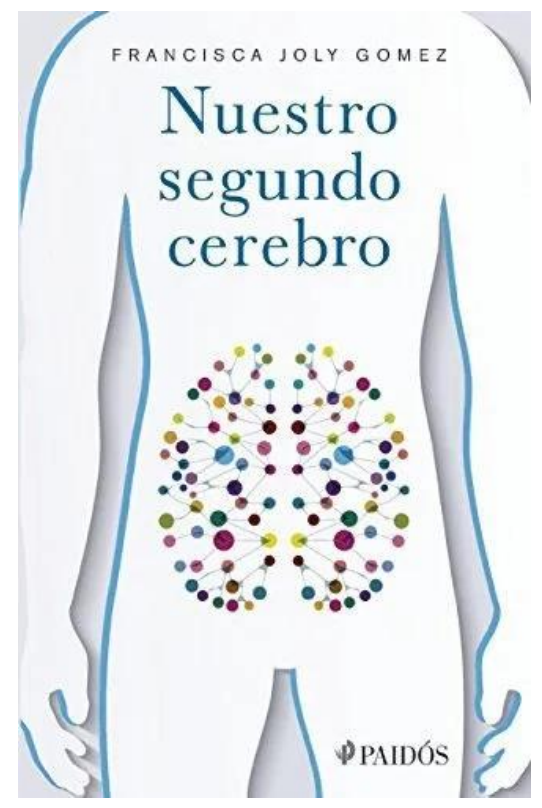

